Al1103 085732

Standard Reference Materials:

\author{
COMPARISON OF ORIGINAL \\ AND SUPPLEMENTAL SRM 705, \\ NARROW MOLECULAR WEIGHT \\ DISTRIBUTION POLYSTYRENE
}

U.S. ARTMENT OF MMMERCE National QC 100 457 0.33 1972 c. 2 . 


\section{NATIONAL BUREAU OF STANDARDS}

The National Bureau of Standards ${ }^{1}$ was established by an act of Congress March 3, 1901. The Bureau's overall goal is to strengthen and advance the Nation's science and technology and facilitate their effective application for public benefit. To this end, the Bureau conducts research and provides: (1) a basis for the Nation's physical measurement system, (2) scientific and technological services for industry and government, (3) a technical basis for equity in trade, and (4) technical services to promote public safety. The Bureau consists of the Institute for Basic Standards, the Institute for Materials Research, the Institute for Applied Technology, the Center for Computer Sciences and Technology, and the Office for Information Programs.

THE INSTITUTE FOR BASIC STANDARDS provides the central basis within the United States of a complete and consistent system of physical measurement; coordinates that system with measurement systems of other nations; and furnishes essential services leading to accurate and uniform physical measurements throughout the Nation's scientific community, industry, and commerce. The Institute consists of a Center for Radiation Research, an Office of Measurement Services and the following divisions:

Applied Mathematics-Electricity-Heat-Mechanics-Optical Physics-Linac Radiation ${ }^{2}$ - Nuclear Radiation ${ }^{2}$ - Applied Radiation ${ }^{2}$ - Quantum Electronics ${ }^{3}$ Electromagnetics ${ }^{3}$-Time and Frequency ${ }^{3}$ - Laboratory Astrophysics ${ }^{3}-$ Cryogenics ${ }^{3}$.

THE INSTITUTE FOR MATERIALS RESEARCH conducts materials research leading to improved methods of measurement, standards, and data on the properties of well-characterized materials needed by industry, commerce, educational institutions, and Government; provides advisory and research services to other Government agencies; and develops, produces, and distributes standard reference materials. The Institute consists of the Office of Standard Reference Materials and the following divisions:

Analytical Chemistry-Polymers-Metallurgy-Inorganic Materials-Reactor Radiation-Physical Chemistry.

THE INSTITUTE FOR APPLIED TECHNOLOGY provides technical services to promote the use of available technology and to facilitate technological innovation in industry and Government; cooperates with public and private organizations leading to the development of technological standards (including mandatory safety standards), codes and methods of test; and provides technical advice and services to Government agencies upon request. The Institute also monitors NBS engineering standards activities and provides liaison between NBS and national and international engineering standards bodies. The Institute consists of the following divisions and offices:

Engineering Standards Services-Weights and Measures-Invention and Innovation-Product Evaluation Technology-Building Research-Electronic Technology-Technical Analysis-Measurement Engineering-Office of Fire Programs.

THE CENTER FOR COMPUTER SCIENCES AND TECHNOLOGY conducts research and provides technical services designed to aid Government agencies in improving cost effectiveness in the conduct of their programs through the selection, acquisition, and effective utilization of automatic data processing equipment; and serves as the principal focus within the executive branch for the development of Federal standards for automatic data processing equipment, techniques, and computer languages. The Center consists of the following offices and divisions:

Information Processing Standards-Computer Information-Computer Services -Systems Development-Information Processing Technology.

THE OFFICE FOR INFORMATION PROGRAMS promotes optimum dissemination and accessibility of scientific information generated within NBS and other agencies of the Federal Government; promotes the development of the National Standard Reference Data System and a system of information analysis centers dealing with the broader aspects of the National Measurement System; provides appropriate services to ensure that the NBS staff has optimum accessibility to the scientific information of the world, and directs the public information activities of the Bureau. The Office consists of the following organizational units:

Office of Standard Reference Data-Office of Technical Information and Publications-Library-Office of International Relations.

\footnotetext{
${ }^{1}$ Headquarters and Laboratories at Gaithersburg, Maryland, unless otherwise noted; mailing address Washington, D.C. 20234 
Standard Reference Materials:

Comparison of Original and Supplemental SRM 705, Narrow Molecular Weight Distribution Polystyrene

Herman L. Wagner

Polymers Division

Institute for Materials Research

National Bureau of Standards

Washington, D.C. 20234

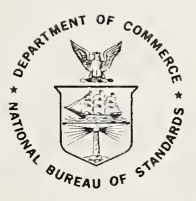

U.S. DEPARTMENT OF COMMERCE, Peter G. Peterson, Secretary NATIONAL BUREAU OF STANDARDS, Lawrence M. Kushner, Acting Director

Issued May 1972 
Library of Congress Catalog Card Number: 72-600099

National Bureau of Standards Special Publication 260-33

Nat. Bur. Stand. (U.S.), Spec. Publ. 260-33, 30 pages (May 1972)

CODEN: XNBSAV

Issued May 1972 
Standard Reference Materials (SRM's) as defined by the National Bureau of Standards are "well-characterized materials, produced in quantity, that calibrate a measurement system to assure compatability of measurement in the nation." SRM's are widely used as primary standards in many diverse fields in science, industry, and technology, both within the United States and throughout the world. In many industries traceability of their quality control process to the national measurement system is carried out through the mechanism and use of SRM's. For many of the nation's scientists and technologists it is therefore of more than passing interest to know the details of the measurements made at NBS in arriving at the certified values of the SRM's produced. An NBS series of papers, of which this publication is a member, called the NBS Special Publication - 260 Series is reserved for this purpose.

This 260 Series is dedicated to the dissemination of information on all phases of the preparation, measurement, and certification of NBS-SRM's. In general, much more detail will be found in these papers than is generally allowed, or desirable, in scientific journal articles. This enables the user to assess the validity and accuracy of the measurement processes employed, to judge the statistical analysis, and to learn details of techniques and methods utilized for work entailing the greatest care and accuracy. It is also hoped that these papers will provide sufficient additional information not found on the certificate so that new applications in diverse fields not foreseen at the time the SRM was originally issued will be sought and found.

Inquiries concerning the technical content of this paper should be directed to the author(s). Other questions concerned with the availability, delivery, price, and so forth will receive prompt attention from:

Office of Standard Reference Materials National Bureau of Standards Washingtor, D.C. 20234 
NBS Spec. Publ. 260, Catalog of Standard Reference Materials, July 1970. 75 cents.* (Supersedes NBS Misc. Publ. 260, January 1968 and NBS Misc. Publ. 241, Iarch 1962.)

NBS Misc. Publ. 260-1, Standard Reference Materials: Preparation of NBS White Cast Iron Spectrochemical Standards, June 1964. 30 cents.*

NBS Misc. Publ. 260-2, Standard Reference Materials: Preparation of NBS Copper-Base Spectrochemical Standards, October 1964. 35 cents.*

NBS Misc. Publ. 260-3, Standard Reference Materials: Metallographic Characterization of an NBS Spectrometric Low-Alloy Steel Standard, October 1964. 20 cents.* (Out of print).

NBS Misc. Publ. 260-4, Standard Reference Materials: Sources of Information on Standard Reference Materials, February 1965. 20 cents.* (Out of print).

NBS Misc. Publ. 260-5, Standard Reference Materials: Accuracy of Solution X-Ray Spectrometric Analysis of Copper-Base Alloys, March 1965. 25 cents.* (Out of print).

NBS Misc. Publ. 260-6, Standard Reference Materials: Methods for the Chemical Analysis of White Cast Iron Standards, July 1965. 45 cents.*

NBS Misc. Publ, 260-7, Standard Reference Materials: Methods for the Chemical Analysis of NBS Copper-Base Spectrochemical Standards, October 1965. 60 cents.*

NBS Misc. Publ. 260-8, Standard Reference Materials: Analysis of Uranium Concentrates at the National Bureau of Standards, December 1965. 60 cents.* (out of print).

NBS Misc. Publ. 260-9, Standard Reference Materials: Half Lives of Materials Used in the Preparation of Standard Reference Materials of Nineteen Radioactive Nuclides Issued by the National Bureau of Standards, November 1965. 15 cents.*

NBS Misc. Publ. 260-10, Standard Reference Materials: Homogeneity Characterization on NBS Spectrometric Standards II: Cartridge Brass and Low-Alloy Steel, December 1965. 30 cents.* 
NBS Misc. Publ. 260-1l, Standard Reference Materials: Viscosity of a Standard Lead-Silica Glass, November 1966. 25 cents.*

NBS Misc. Publ. 260-12, Standard Reference Materials: Homogeneity Characterization of NBS Spectrometric Standards III: White Cast Iron and Stainless Steel Powder Compact, September 1966. 20 cents.*

NBS Misc. Publ. 260-13, Standard Reference Materials: Mössbauer Spectroscopy Standard for the Chemical Shift of Iron Compounds, July 1967. 40 cents.*

NBS Misc. Publ. 260-14, Standard Reference Materials: Determination of Oxygen in Ferrous Materials -SRM 1090, 1091, and 1092, September 1966. 30 cents.*

NBS Misc. Publ. 260-15, Standard Reference Materials: Recommended Method of Use of Standard Light-Sensitive Paper for Calibrating Carbon Arcs Used in Testing Textiles for Colorfastness to Light, June 1967. 20 cents.*

NBS Spec. Publ. 260-16, Standard Reference Materials: Homogeneity Characterization of NBS Spectrometric Standards IV: Preparation. and Microprobe Characterization of W-20\% Mo Alloy Fabricated by Powder Metallurgical Methods, January 1969. 35 cents.*

NBS Spec. Publ. 260-17, Standard Reference Materials: Boric Acid; Isotopic and Assay Standard Reference Materials, February 1970. 65 cents.*

NBS Spec. Publ. 260-18, Standard Reference Materials: Calibration of NBS Secondary Standard Magnetic Tape (Computer Amplitude Reference) Using the Reference Tape Amplitude Measurement "Process A", November 1969. 50 cents.*

NBS Spec. Publ. 260-19, Standard Reference Materials: Analysis of Interlaboratory Measurements on the Vapor Pressure of Gold (Certification of Standard Reference Material 745), January 1970. 30 cents.*

NBS Spec. Publ. 260-20, Standard Reference Materials: Preparation and Analysis of Trace Element Glass Standards. (In preparation)

NBS Spec. Publ. 260-21, Standard Reference Materials: Analysis of Interlaboratory Measurements on the Vapor Pressures of Cadmium and Silver, January 1971. 35 cents.* 
NBS Spec. Publ. 260-22, Standard Reference Materials: Homogeneity Characterization of Fe-3Si Alloy, February 1971. 35 cents.*

NBS Spec. Publ. 260-23, Standard Reference Materials: Viscosity of a Standard Borosilicate Glass, December 1970. 25 cents.*

NBS Spec. Publ. 260-24, Standard Reference Materials: Comparison of Redox Standards, January 1972. \$1.00.*

NBS Spec. Publ. 260-25, Standard Reference Materials: A Standard Reference Material Containing Nominally Four Percent Austenite, February 1971. 30 cents.*

NBS Spec. Publ. 260-26, Standard Reference Materials: National Bureau of Standards-U.S. Steel Corporation Joint Program for Determining Oxygen and Nitrogen in Steel, February 1971. 50 cents.*

NBS Spec. Publ. 260-27, Standard Reference Materials: Uranium Isotopic Standard Reference Materials, April 1971. \$1.25.*

NBS Spec. Publ. 260-28, Standard Reference Materials: Preparation and Evaluation of SRM's 481 and 482 Gold-Silver and Gold-Copper Alloys for Microanalysis, August 1971. $\$ 1.00 . *$

NBS Spec. Publ. 260-29, Standard Reference Materials: Calibration of NBS Secondary Standard Magnetic Tape (Computer Amplitude Reference) Using the Reference Tape Amplitude Measurement "Process A-Model 2", June 1971. 60 cents.*

NBS Spec. Publ. 260-30, Standard Reference Materials: Standard Samples Issued in the USSR (A Translation from the Russian), June 1971. \$1.00.*

NBS Spec. Publ. 260-31, Standard Reference Materials: Thermal Conductivity of Electrolytic Iron SRM 734 from 4 to $300 \mathrm{~K}$, November 1971. 35 cents.*

NBS Spec. Publ. 260-32, Standard Reference Materials: The Cooperative Study of Temperature Scale Standards for DTA by ICTA and NBS. (In preparation)

NBS Spec. Publ. 260-33, Standard Reference Materials: Comparison of Original and Supplemental SRM 705, Narrow Molecular Weight Distribution Polystyrene, H. L. Wagner. (This publication). 
NBS Spec. Publ. 260-34, Standard Reference Materials: Thermoelectric Voltage. (In preparation).

NBS Spec. Publ. 260-35, Standard Reference Materials: Thermal Conductivity of Austenitic Stainless Steel, SRM 735 from 5 to 280K*, April 1972. 35 cents.*

NBS Spec. Publ. 260-36, Standard Reference Materials: A Referee Method for the Determination of Calcium in Serum. SRM 736. (WERB)

NBS Spec. Publ. 260-37, Standard Reference Materials: Methods of Analysis of NBS Clay Standards. (In preparation).

NBS Spec. Publ. 260-38, Standard Reference Materails: Preparation and Calibration of Standards of Spectral Specular Reflectance. (In preparation).

NBS Spec. Publ. 260-39, Standard Reference Materials; The Eddy Current Decay Method for Resistivity Characterization of High-Purity Metals. (In preparation).

* Send order with remittance to: Superintendent of Documents, U.S. Government Printing Office, Washington, D.C. 20402. Remittance from foreign countries should include an additional one-fourth of the purchase price for postage. 



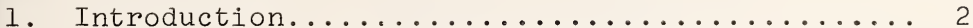

2. Weight Average Molecular Weight by Light

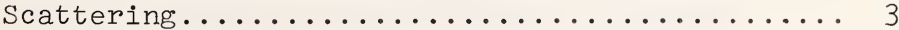

3. Number Average Molecular Weight by Osmometry.... 8

4. Limiting Viscosity Numbers............... 12

5. Gel Permeation Chromatography Measurements...... 13

6. Determination of Pellet to Pellet Variation..... 15

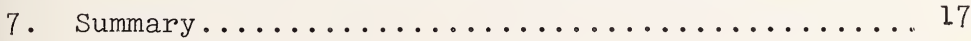

8. References......................... 18

Appendix .I.................. I9

LIST OF TABLES

PAGE

Table No.

1. Direct Comparison of 705-705A by Light

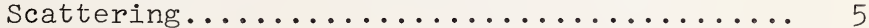

2. Additional Determinations of $\mathrm{M}_{\mathrm{W}}$ on $705 \ldots \ldots 66$

3. Comparison of $\mathrm{M}_{\mathrm{W}}$ for $705-705 \mathrm{~A} \ldots \ldots \ldots \ldots \ldots \ldots$

4. Number Average Molecular Weight $(\mathrm{II} / \mathrm{c})^{1 / 2}$

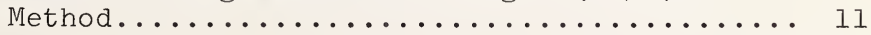

5. Limiting Viscosity Number in Cyclohexane at $35^{\circ} \mathrm{C}$

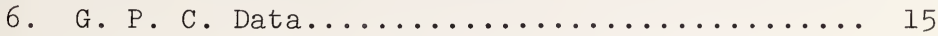


Figure No.

1. Comparison of gel permeation chromatograms of 705 and $705 \mathrm{~A}$. . . . . . . . .

2. Viscosity numbers for samples of 705 . . . 17 
COMPARISON OF ORIGINAL AND SUPPLEMENTAL SRM 705, NARROW MOLECULAR WEIGHT DISTRIBUTION POLYSTYRENE

Herman L. Wagner

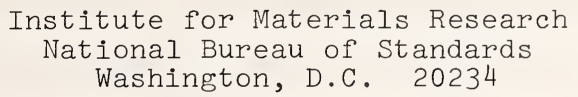

Because the supply of the original batch of narrow molecular weight distribution polystyrene, SRM 705, is almost exhausted, another supply of polystyrene, reported to be from the same batch as the original has been characterized to determine whether it is the same as the original as far as the properties listed on the certificate are concerned. No difference in molecular weight as measured by light-scattering, osmometry, or gel-permeation chromatography could be found. The limiting viscosity numbers were also the same. It was also shown from solution viscosity measurements that pellet to pellet variation in molecular weight is negligible.

Key words: Characterized polymers; narrow molecular weight polystyrene; polystyrene standard; Standard Reference Material 705. 


\section{INTRODUCTION}

Early in 1963 the National Bureau of Standards issued its first polymer Standard Reference Material, SRM 705 [1], a narrow molecular weight distribution polystyrene. Recently the original supply of one of these, SRM 705, became very low, but additional material, which had previously been sent to the Bureau by Dow Chemical Company, was available. According to the letter by Dr. H. W. McCormick of Dow Chemical Company, Midland, Michigan, dated September 7, 1966, to Dr. Emanuel Horowitz, this additional supply is the same as the original. Because this is a certified material, however, it was necessary to compare the original and the new material to make certain that the two are indistinguishable as far as the properties listed on the certificate are concerned. About 4900 grams of this second sample are available and will be referred to as SRM $705 \mathrm{~A}$ in this report only.

This polystyrene, produced by Dr. McCormick's group at Dow Chemical Company by large scale anionic techniques, has a very narrow molecular weight distribution-- $\mathbb{M}_{W} / M_{n}$ of about 1.12. It had been certified previously by Dr. D. McIntyre and his group at the National Bureau of Standards for weight average molecular weight by light scattering and sedimentation equilibrium, number average molecular weight by membrane osmometry, and limiting viscosity number in benzene and cyclohexane. A copy of the certificate is shown in Appendix 1 . 
In the present study SRM 705 and 705A were compared for weight average molecular weight, for number average molecular weight and for limiting viscosity number. In addition they were compared for molecular weight distribution by gel permeation chromatography, a technique which was not available at the time the SRM 705 was originally issued. No comparison was made in this work using the ultracentrifuge.

In the discussion which follows no attempt is made to describe equipment or techniques where this has already been done satisfactorily elsewhere. However, when changes were made in the standard procedure, or when there is no common standard procedure, details of the method are given.

2. WEIGHT AVERAGE MOLECULAR WEIGHT BY LIGHT SCATTERING

A comparison of the weight average molecular weight of SRM 705 and SRM 705A was made using the "Sofica" photo-gonio diffusometer, Model 701 (Bausch and Lomb, Rochester, New York).* A general description of the light scattering

* Certain commercial equipment, instruments, or materials are identified in this paper in order to adequately specify the experimental procedure. In no case does such identification imply recommendation or endorsement by the National Bureau of Standards, nor does it imply that the material or equipment identified is necessarily the best available for the purpose. 
method may be found in several places, as for example in the chapter by Chiang [2]. For a description of the specific techniques used in this laboratory, the paper on light scattering in the series [3] describing the certification of SRM 1475, linear polyethylene, is recommended. Determinations were carried out in cyclohexane, at the theta temperature, $35^{\circ} \mathrm{C}$, with unpolarized light at $5460 \mathrm{~A}$. It was generally found that less scatter was obtained in the data by placing an additional 54609 light filter just before the detector photocell. It is possible that this filter removed extraneous radiation due to fluorescence in the polymer solution.

The instrument was calibrated with benzene, for which the Rayleigh ratio is taken as $15.8 \times 10^{-6} \mathrm{~cm}^{-1}$ [4]. In practice, a special glass rod is used as a working standard, after comparison of its scattering with the pure benzene.

Six different concentrations, ranging from about $1 \times 10^{-3} \mathrm{~g} / \mathrm{ml}$ to $5 \times 10^{-3} \mathrm{~g} / \mathrm{ml}$ of each polymer were measured. Each solution was made up independently by weight and then filtered through "Millipore" filters of $0.22 \mu \mathrm{m}$, nominal pore size, to remove dust and other particulate matter which might interfere with scattering at low angles. The solutions were kept at $40{ }^{\circ} \mathrm{C}$ until measured at $35{ }^{\circ} \mathrm{C}$. Replicate measurements were made on two different samples of each solution. 
The value of the refractive index increment, dn/dc for the polystryrene-cyclohexane system at $35^{\circ} \mathrm{C}$ was taken as $0.1705 \mathrm{ml} / \mathrm{g}[5]$.

The value of $\mathrm{c} / \mathrm{I}$ for each concentration was plotted against $\sin ^{2} \theta / 2$ and extrapolated visually to $\theta=0$. All these extrapolated c/I's were then plotted against concentration and again extrapolated to $c=0$. A similar procedure was followed for these values of $\mathrm{c} / \mathrm{I}$, at each specified angle, as a function of concentration. The values of $c / I$ extrapolated to $c=0$ for each angle were then plotted against $\sin ^{2} \theta / 2$ to find the value of $c / I$ at $\theta=0$. The mean of this value and the value obtained at $c=0$, which almost always were within $1 / 2 \%$ of each other, was used to obtain 1/M upon multiplication by the appropriate factor. The results follow:

Table 1. Direct Comparison of $705-705 \mathrm{~A}$ by Light scattering.

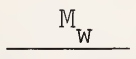

Sample 705:

182,300

183,900

Average 183,100

705A:

183,000

184,100

Average 183,550

Certificate value:

179,300 
It was possible, because of the availability of some subsequent determinations on 705 , made in another connection, to obtain a better value for the mean and standard deviation. These additional determinations gave the following values:

Table 2. Additional Determinations of $\mathrm{M}_{\mathrm{W}}$ on 705 .

183,000
177,500
180,900
182,700
Mean $\quad \begin{aligned} & 177,100 \\ & \end{aligned} \quad 180,240$

As shown in Table 3, the difference between the mean for the first set, (Table I) and the above is 2860 , well within the $95 \%$ confidence limits of the difference. Hence we may assume that the two sets of data may be treated as one set.

If we compare the mean of this combined set, 181,111, with the mean for 705A, 183,550 (Table 1) we find that the difference, 2539, between the two is also within the 95\% confidence limits value, 4,900. This is also shown in Table 3. Hence there is no evidence of a difference between the two materials.

We also conclude that there is no difference between the value on the certificate and the value now obtained for 705, again as seen in Table 3. It should be noted that since there is no reason to believe that the standard 


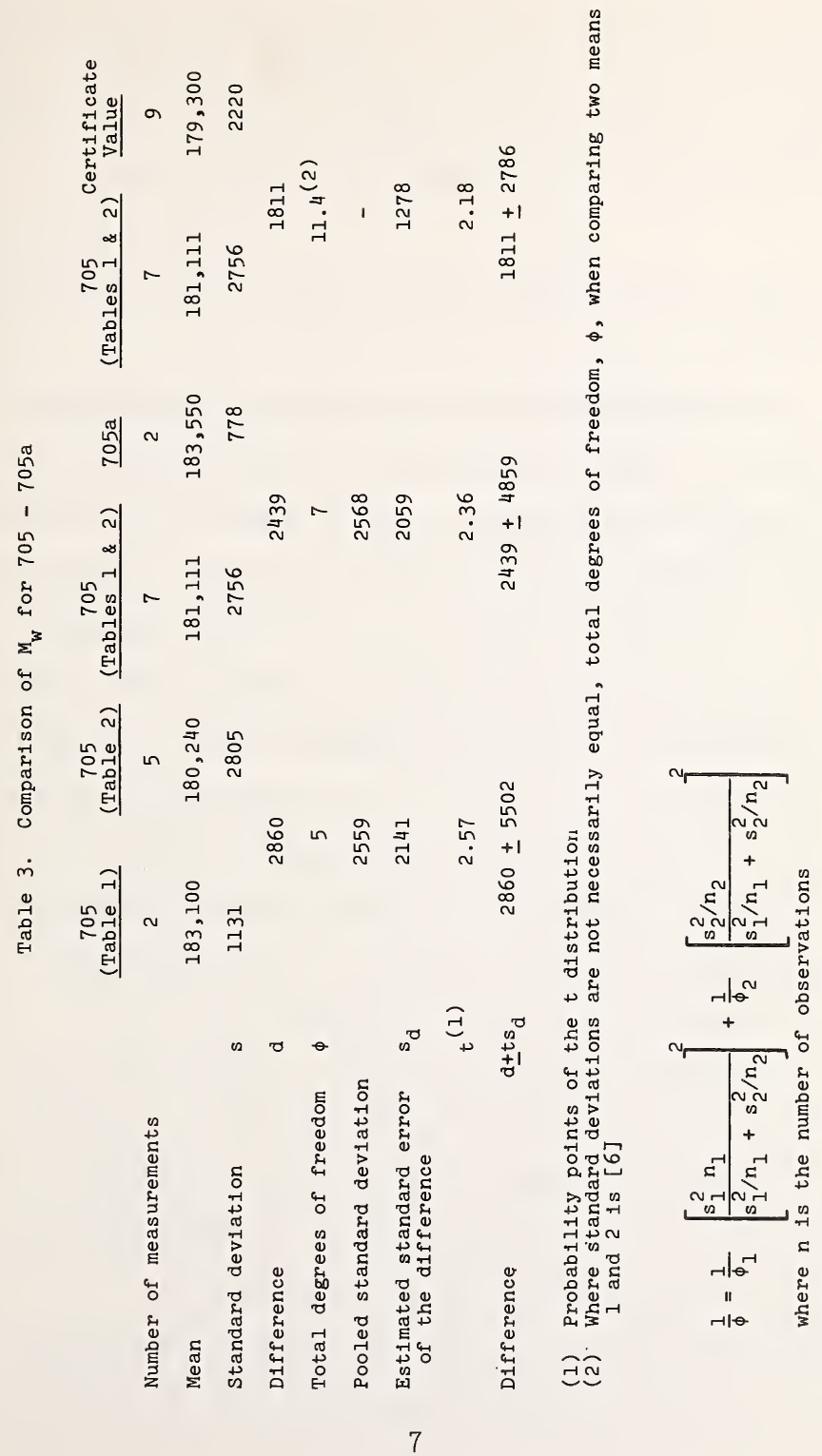


deviations of the present set of measurements and of the certificate value are equal, the standard deviations were not pooled. In addition, the number of degrees of freedom was estimated by the method shown in the footnotes to Table 3 .

In other cases shown in Table 3 the standard deviations were pooled.

3. NUMBER AVERAGE MOLECULAR WEIGHT BY OSMOMETRY Number average molecular weight was determined by osmotic pressure measurements. Techniques for determining the number average molecular weight by osmotic pressure are described in the literature $[7,8]$. The details of the method used in this laboratory are included in the paper on osmometry describing the certification of SRM 1475 [9]. These were made with a Hewlett-Packard Membrane Osmometer, Model 502, which is characterized by rapid response time (a few minutes), negligible solvent transfer across the membrane, and small sample volume $(0.3 \mathrm{ml})$. The semipermeable membranes were gel cellophane, type $450 \mathrm{D}$, obtained from Arro Laboratories, Inc. These, when received, are in an isopropanol-water solution. They are then conditioned by soaking successively in ethanol, 1:1 ethanol-acetone, I:I acetone-toluene, and finally pure toluene, the solvent used for the measurements.

When the osmotic pressure measurements were begun, it was not known that the pellet-to-pellet variability was 
negligible, as shown by the viscosity measurements described below. To eliminate the effects of possible pellet-to-pellet variability and to bring both materials to the same physical condition, particularly moisture content, the following procedure was utilized.

Five replicate one-gram blends of pellets of 705 and 705A were separately dissolved in benzene and freeze dried. From each of these ten samples, five independent concentrations, ranging from $0.25 \mathrm{~g} / 100 \mathrm{ml}$ to about $1.1 \mathrm{~g} / 100 \mathrm{ml}$ were made up in toluene to give a total of 50 solutions. The osmotic pressure, $I$, of each of these was measured twice at $25^{\circ} \mathrm{C}$.

The limiting values of $\Pi / c$ as the concentration, $c$, approaches zero were determined for each of these ten solutions in three ways.

1. linear least squares $\Pi / \mathrm{c}$ vs $\mathrm{c}$

2. linear least squares $(\pi / c)^{1 / 2}$ vs $c$

3. least squares - polynomial $I=d_{1} c+d_{2} c^{2}+d_{3} c^{3}$

Method 3, which is perhaps the most desirable of the above methods for treating the data, gave, with our computer program, at least one result that was extremely sensitive to one point that was just off a smooth curve. Further investigation is needed before a satisfactory method of fitting such data to a polynomial is found. For our immediate needs, it was sufficient to compare the results for the two polymers obtained by method 2 above, i.e., plotting $(\pi / \mathrm{c})^{1 / 2} \mathrm{vs} \mathrm{c}$ 
and determining the limiting value of $(\pi / c)^{1 / 2}$ from the intercept at $c=0$ by a linear least squares computation. This limiting value is inversely proportional to the square root of the molecular weight. The results are shown in Table 4, where (I/c) o represents the square of this limiting value.

To determine whether the difference between the averages of $\mathrm{M}_{\mathrm{n}}$ for the two--162,400 for 705 and 165,200 for 705A--is significant, the same procedure was employed as in the light scattering case. A combined standard error of 3,500 is found for the two sets of data, and since this, when multiplied by a $t$ value of 2.31 for 8 degrees of freedom, gives, for 95\% confidence limits, a value of 8,000 , we conclude that the difference of the two number average means of 2,800 is not significant.

If the $705 \mathrm{~A}$ value is compared with the certificate value of 170,900 , determined in cyclohexane at $35^{\circ} \mathrm{C}$ with a standard deviation of the average 580 (number of determinations was 12), the estimated standard error of the difference is 2,960 with 4 degrees of freedom, calculated as shown in Table 3. The $t$ value is 2.78 which when multiplied by the combined standard error above gives a 95\% confidence limit of 8,200, indicating that the difference of 5,680 molecular weight units is not significant. The standard error of 580 in the certificate is surprisingly low but since the details of this determination 
are not available, it is difficult to make a comparison with our experiments.

\section{LIMITING VISCOSITY NUMBERS}

Limiting viscosity number, L.V.N., was determined in the usual way by extrapolation, to zero concentration, of viscosity number $\left(n / n_{0}-1\right) / c$, where $n^{\prime} n_{0}$ is the relative viscosity of solution to solvent, and $c$ is the concentration in $\mathrm{g} / \mathrm{ml}$. The measurements were made in a Ubbelohde viscometer. A Hewlett-Packard, Model 5901B Autoviscometer, was used to operate the viscometer and measure the flow times, while the viscometer was thermostatted in a Hewlett-Packard $5901 \mathrm{~A}$ Constant Temperature Bath. With this system, flow times of about 40 or 50 seconds for a given solution are reproducible to about 0.03 seconds, making it possible to use fairly dilute solutions and thereby increasing the reliability of the extrapolation to zero concentration. Six solutions of each sample in distilled cyclohexane, ranging in concentration from $.004 \mathrm{~g} / \mathrm{ml}$ to $0.1 \mathrm{~g} / \mathrm{ml}$ were measured at $35^{\circ} \mathrm{C}$. As in the case for light scattering, the solutions were kept at $40{ }^{\circ} \mathrm{C}$ until used. The results were:

Table 5. Limiting Viscosity Number in Cyclohexane at $35^{\circ} \mathrm{C}$.

705

$705 \mathrm{~A}$

Certificate value

$$
\frac{\mathrm{L} \cdot \mathrm{V} \cdot \mathrm{N}}{35 \cdot 2 \mathrm{ml} / \mathrm{g}}
$$

$35 \cdot 3$ $\frac{\text { Standard Deviation }}{0.2}$

0.1

35.4 $0.24 *$

* "Standard deviation of average, for six samples". 
Again there is no evidence for a difference between 705 and 705A, nor between their average and the certificate value.

5. GEL PERMEATION CHROMATOGRAPHY MFASUREMENTS

The two samples were compared by gel permeation chromatography, a column fractionation method that has come into general use in recent years for the determination of molecular weight distribution of high polymers.

The gel permeation chromatograph used was the Model 200 (analytical scale) G.P.C. manufactured by Waters Associates, 61 Fountain Street, Framingham, Massachusetts. It was run at $100^{\circ} \mathrm{C}$ with 1,2,4-trichlorobenzene as the solvent, at a concentration of $0.3 \%$.

Since only the difference between 705 and $705 \mathrm{~A}$ was of interest, an absolute, carefully determined independent calibration was not required. Instead two anionically produced polystyrenes, supplied by Waters Associates, with molecular weight falling on either side of the SRM 705 value (41,000 and 98,000) and the SRM 705 (certificate value $\mathrm{M}_{\mathrm{W}}=179,300$ ) were run to give the following calibration:

$$
\log M=11.89-0.204 \mathrm{~V}_{\mathrm{e}}
$$

where $V_{e}$ is the peak elution volume.

Visual comparison of the charts (figure 1) for runs made under the same conditions for 705 and $705 \mathrm{~A}$ show that the peaks occur at the same elution volume. Calculation of the number, weight and $z$ average molecular weights, given 


\section{GEL PERMEATION CHROMATOGRAMS}

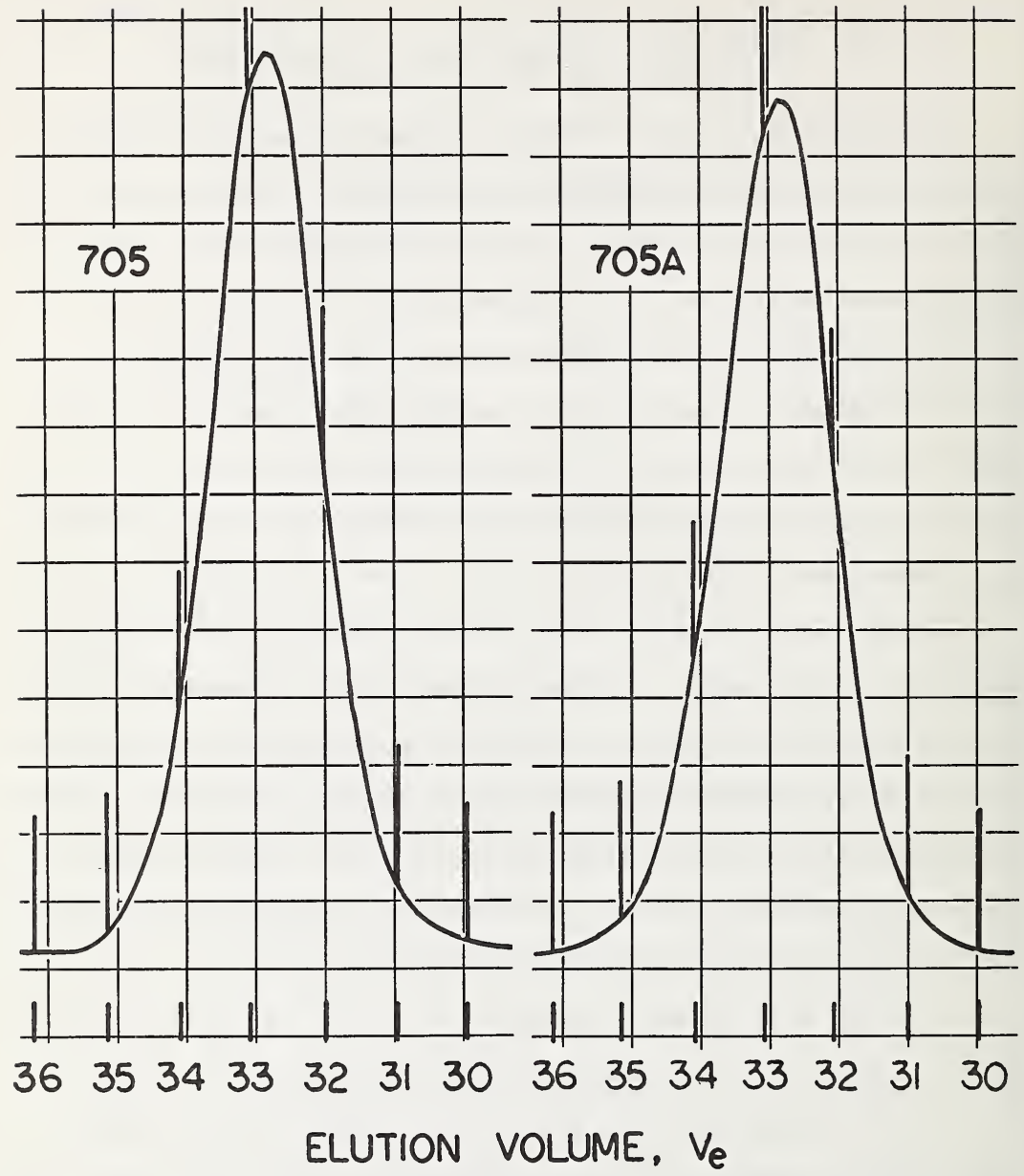

Figure 1. Comparison of gel permeation chromatograms of 705 and $705 \mathrm{~A}$. 
in Table 6, show that no significant differences in distribution occur. If the curves in figure 1 were normalized, they would be superimposable.

Table 6. G. P. C. Data.

\begin{tabular}{|c|c|c|c|c|}
\hline \multirow{3}{*}{705} & Run & $M_{n}$ & $\mathrm{M}_{\mathrm{W}}$ & $\mathrm{M}_{\mathrm{z}}$ \\
\hline & 1 & 155,600 & 178,200 & 206,000 \\
\hline & 2 & 155,900 & 177,900 & 204,000 \\
\hline \multirow[t]{2}{*}{$705 \mathrm{~A}$} & 1 & 157,000 & 180,200 & 208,000 \\
\hline & 2 & 157,800 & 181,500 & 211,000 \\
\hline
\end{tabular}

The replication is insufficient to provide a good measure of the reproducibility among solutions. However, the difference in molecular weights found between 705 and $705 \mathrm{~A}$ is of the order of about $2 \%$, which we know from previous experience to be statistically insignificant, so we again conclude that there is no evidence of an important difference between the two materials.

Because of the method of calibration, the molecular weights quoted above should not be considered absolute.

\section{DETERMINATION OF PELLET TO PELLET VARIATION}

Since the polymer pellets weigh only between 7 to 20 mg, there are only two techniques available to us which take a small enough sample size, namely G. P. C. and solution viscosity, with which to obtain a measure of variation in molecular weight from pellet to pellet. Since in our case 
viscosity measurements are more sensitive to small changes in molecular weight than G. P. C., the former was used. It was possible to obtain meaningful results with a "semimicro" Cannon-Ubbelohde viscometer which takes a one milliliter sample. Single pellets were dissolved in 5 to $10 \mathrm{ml}$ of benzene and measured at $35^{\circ} \mathrm{C}$. Because of variation in pellet weight, it was not convenient to keep the concentration constant, so that the following procedure was used to estimate the variation in viscosity. The viscosity number $\left(n / \eta_{0}-1\right) / c$ for each pellet is computed from flow times of solvent and solution, corrected for kinetic energy effects, and is plotted against concentration. These are shown in figure 2, together with the line representing the linear least squares fit of the points. The standard deviation of the points about the line is about $0.3 \%$ of the value of the intercept on the viscosity number axis, or the limiting viscosity number. This represents the sum of measurement error and pellet to pellet variation in viscosity or molecular weight. From previous measurements it has been established that measurement error itself leads to a standard deviation of $0.3 \%$, leading to the conclusion that the variation in viscosity, and hence molecular weight, from pellet to pellet, is negligible. 


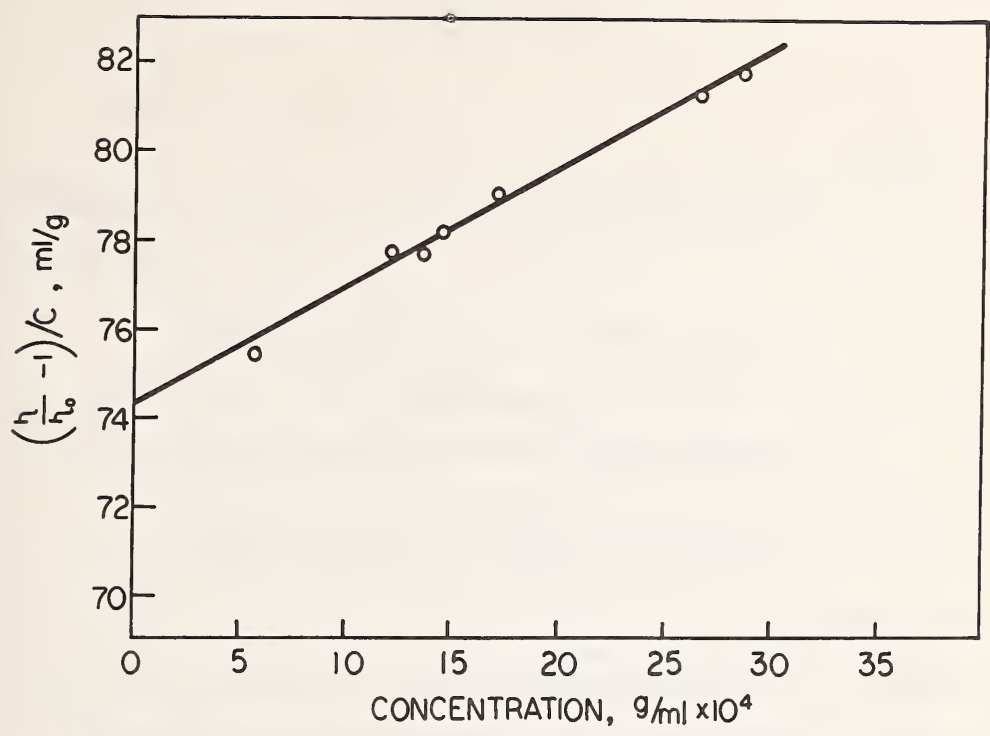

7. SUMMARY

No evidence of a difference between 705 and $705 \mathrm{~A}$ can be shown to exist. From solution viscosity measurements it was shown that pellet to pellet variation in molecular weight is negligible.

The author acknowledges the assistance of $\mathrm{J}$. E. Brown, R. G. Christensen, and J. R. Maurey who carefully performed the measurements discussed in this report. He is also grateful to Dr. John Mandel for helpful discussion of the statistical analyses employed. 


\section{REFERENCES}

[1] McIntyre, D., J. Res. Nat. Bur. Stand. (U.S.), 71A, 43(1967).

[2] Chiang, R., Newer Methods of Polymer Characterization, Bacon, Ke, (ed.), (Interscience Publishers, New York, $1964)$.

[3] Frolen, L. J., Ross, G. S., Wims, A. M., and Verdier, P. H., J. Res. Nat. Bur. Stand. (U.S.), in preparation.

[4] Coumou, D. J., J. of Colloid Sci. 15, 408(1960).

[5] O'Mara, J. H. and McIntyre, D., J. Phys. Chem. 63, $1435(1959)$.

[6] Davies, 0. L., Statistical Methods in Research and Production, (Oliver and Boyd, London, 1961).

[7] Hookway, H. T., Techniques of Polymer Characterization, Allen, P. W., (ed.), (Butterworths, London, 1959).

[8] Bonnar, R. V., Dimbat, M., Stross, F. H., Number Average Molecular Weights, (Interscience Publishers, New York, $1958)$.

[9] Brown, J. and Verdier, P. H., J. Res. Nat. Bur. of Stand., in preparation. 
U. S. Department of Commerce Maurice H. Stans Secretary

National Boreaü of Standard
THIS IS A PRELIMINARY ISSUE OF THE PRINTED CERTIFICATE

WHICH WILL BE AVAILABLE WITHIN 60 DAYS

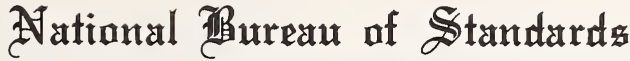 \\ Uiertifitate}

Standard Reference Material 705

Polystyrene

(Narrow Molecular Weight Distribution)

Donald McIntyre

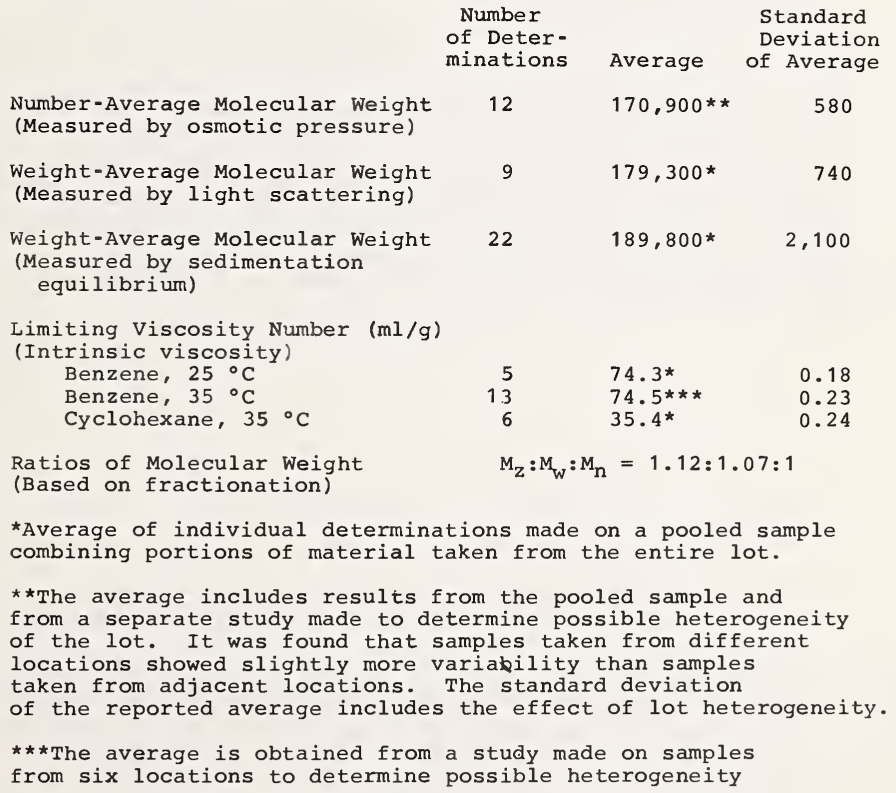

(over) 
of the lot. It was found that samples taken from different locations showed slightly more variability than samples taken from adjacent locations. The standard deviation of the reported average includes the effect of lot heterogeneity.

Washington, D. C. 20234 November 6, 1969 (Revised February 25, 1972)

J. Paul Cali, Chief Office of Standard Reference Materials

The polystyrene sample was prepared by the polymerization of styrene in benzene using butyllithium as an initiator. Ash content is $0.05 \%$ of sample. Volatile content is about $0.5 \%$. Determinations of molecular weight and intrinsic viscosity are based on sample weights of the polystyrene pellets uncorrected for volatiles. Each pellet weighs approximately $10 \mathrm{mg}$. Several pellets were always used in the above determinations.

The osmotic pressure measurements were made with \#600 gel cellophane membranes. The light scattering and sedimentation molecular weight determinations were calculated using the following constants for polystyrene-cyclohexane solutions at $35^{\circ} \mathrm{C}: 0.1705 \mathrm{ml} / \mathrm{g}$ for the refractive index increment at $546 \mathrm{~nm}$ and $0.930 \mathrm{ml} / \mathrm{g}$ for the partial specific volume. The maximum rate of shear in the Ubbelohde viscometers used to determine the intrinsic viscosities was about $1500 \mathrm{sec}^{-1}$ for water. The $z$-average $\left(M_{z}\right)$, weight-average $\left(M_{W}\right)$, and number-average $\left(\mathrm{M}_{n}\right)$, molecular weight ratios are based upon a complete viscometric analysis and selected osmometric analysis of 36 fractions. 
FORM NBS-114A (1-71)

U.S. DEPT. OF COMM.

BIBLIOGRAPHIC DATA

SHEET

1. PUBLICATION OR REPORT NO.

NBS SP 260-33

4. TITLE AND SUBTITLE

Standard Reference Materials:

Comparison of Original and Supplemental SRM 705,

Narrow Molecular Weight Distribution Polystyrene

5. Publication Date

May 1972

6. Performin Organization Code

7. AUTHOR(S)

Herman L. Wagner

9. PERF ORMING ORGANIZATION NAME AND ADDRESS

NATIONAL BUREAU OF STANDARDS

DEPARTMENT OF COMMERCE

WASHINGTON, D.C. 20234

12. Sponsoring Organization Name and Address

Same as No. 9

8. Performing Organization

10. Project/Task/Work Unit No.

11. Contract/Grant No.

13. Type of Report \& Period Covered

Final

14. Sponsoring Agency Code

15. SUPPI.EMENT ARY NOTES

16. ABSTRACT (A 200-word or less factual summary of most significant information. If document includes a significant bibliography or literature survey, mention it here.)

Becuase the supply of the original batch of narrow molecular weight distribution polystyrene, SRM 705, is almost exhausted, another supply of polystyrene, reported to be from the same batch as the original has been characterized to determine whether it is the same as the original as far as the properties listed on the certificate are concerned. No difference in molecular weight as measured by light scattering, osmometry, or gel-permeation chromatography could be found. The limiting viscosity numbers were also the same. It was also shown from solution viscosity measurements that pellet to pellet variation in molecular weight is negligible.

17. KEY WORDS (Alphabetical order, separated by semicolons) Characterized polymers; narrow molecular weight polystyrene; polystyrene standard; Standard Reference Material 705.

18. AVAILABILITY STATEMENT

X UNLIMITED.

FOR OFFICIAL DISTRIBUTION. DO NOT RELEASE TO NTIS.

\begin{tabular}{|l|c|}
$\begin{array}{l}\text { 19. SECURITY CLASS } \\
\text { (THIS REPORT) }\end{array}$ & 21. NO. OF PAGES \\
UNCL ASSIF IED & 30 \\
\hline $\begin{array}{l}\text { 20. SECURITY CLASS } \\
\text { (THIS PAGE) } \\
\text { UNCL ASSIFIED }\end{array}$ & 35 cents \\
\hline
\end{tabular}



PERIODICALS

JOURNAL OF RESEARCH reports National Bureau of Standards research and development in physics, mathematics, and chemistry. Comprehensive scientific papers give complete details of the work, including laboratory data, experimental procedures, and theoretical and mathematical analyses. Illustrated with photographs, drawings, and charts. Includes listings of other NBS papers as issued.

Published in two sections, available separately:

\section{- Physics and Chemistry}

Papers of interest primarily to scientists working in these fields. This section covers a broad range of physical and chemical research, with major emphasis on standards of physical measurement, fundamental constants, and properties of matter. Issued six times a year. Annual subscription: Domestic, $\$ 9.50 ; \$ 2.25$ additional for foreign mailing.

\section{Mathematical Sciences}

Studies and compilations designed mainly for the mathematician and theoretical physicist. Topics in mathematical statistics, theory of experiment design, numerical analysis, theoretical physics and chemistry, logical design and programming of computers and computer systems. Short numerical tables. Issued quarterly. Annual subscription: Domestic, \$5.00; $\$ 1.25$ additional for foreign mailing.

\section{TECHNICAL NEWS BULLETIN}

The best single source of information concerning the Bureau's measurement, research, developmental, cooperative, and publication activities, this monthly publication is designed for the industry-oriented individual whose daily work involves intimate contact with science and technology-for engineers, chemists, physicists, research managers, product-development managers, and company executives. Includes listing of all NBS papers as issued. Annual subscription: Domestic, $\$ 3.00 ; \$ 1.00$ additional for foreign mailing.

\section{Bibliographic Subscription Services}

The following current-awareness and literaturesurvey bibliographies are issued periodically by the Bureau: Cryogenic Data Center Current Awareness Service (weekly), Liquefied Natural Gas (quarterly), Superconducting Devices and Materials (quarterly), and Electromagnetic Metrology Current Awareness Service (monthly). Available only from NBS Boulder Laboratories. Ordering and cost information may be obtained from the Program Information Office, National Bureau of Standards, Boulder, Colorado 80302 .

\section{NOHPERIODICALS}

Applied Mathematics Series. Mathematical tables, manuals, and studies.

Building Science Series. Research results, test methods, and performance criteria of building materials, components, systems, and structures.

Handbooks. Recommended codes of engineering and industrial practice (including safety codes) developed in cooperation with interested industries, professional organizations, and regulatory bodies.

Special Publications. Proceedings of NBS conferences, bibliographies, annual reports, wall charts, pamphlets, etc.

Monographs. Major contributions to the technical literature on various subjects related to the Bureau's scientific and technical activities.

National Standard Reference Data Series. NSRDS provides quantitative data on the physical and chemical properties of materials, compiled from the world's literature and critically evaluated.

Product Standards. Provide requirements for sizes, types, quality, and methods for testing various industrial products. These standards are developed cooperatively with interested Government and industry groups and provide the basis for common understanding of product characteristics for both buyers and sellers. Their use is voluntary.

Technical Notes. This series consists of communications and reports (covering both other-agency and NBS-sponsored work) of limited or transitory interest.

Federal Information Processing Standards Publications. This series is the official publication within the Federal Government for information on standards adopted and promulgated under the Public Law 89-306, and Bureau of the Budget Circular A-86 entitled, Standardization of Data Elements and Codes in Data Systems.

Consumer Information Series. Practical information, based on NBS research and experience, covering areas of interest to the consumer. Easily understandable language and illustrations provide useful background knowledge for shopping in today's technological marketplacc.

\section{CATALOGS OF NBS PUBLICATIONS}

NBS Special Publication 305, Publications of the NBS. 1966-1967. When ordering, include Catalog No. C13.10:305. Price $\$ 2.00 ; 50$ cents additional for foreign mailing.

NBS Special Publication 305, Supplement 1, Publications of the NBS, 1968-1969. When ordering, include Catalog No. C13.10:305/Suppl. 1. Price $\$ 4.50 ; \$ 1.25$ additional for foreign mailing.

NBS Special Publication 305, Supplement 2, Publications of the NBS, 1970. When ordering, include Catalog No. G13.10:305/Suppl. 2. Price $\$ 3.25 ; 85$ cents additional for foreign mailing.

Order NBS publications (except Bibliographic Subscription Services) from: Superintendent of Documents, Government Printing Office, Washington, D.C. 20402. 
U.S. DEPARTMENT OF COMMERCE

National Bureau of Standards

Washington, D.C. 20234

DFFICIAL BUSINESS

Penalty for Private Use, $\$ 300$
POSTAGE AND FEES PAID U.S. DEPARTMENT OF COMMERCE 215 